\title{
Methylobacillus: a New Genus of Obligately Methylotrophic Bacteria
}

\author{
JERRY R. YORDY AND TERRY L. WEAVER ${ }^{1}$ \\ Department of Microbiology, Cornell University, Ithaca, New York 14853
}

\begin{abstract}
A new genus and species of obligately methylotrophic bacteria are described. These bacteria are nonmotile, gram-negative rods occurring singly and in pairs. Only methanol and methylamine can support growth. Formaldehyde fixation occurs mainly via the 3-hexulose phosphate pathway, and cell extracts contain a glutathione-independent, nicotinamide adenine dinucleotide-linked formaldehyde dehydrogenase. The deoxyribonucleic acid base composition is $54.1 \mathrm{~mol} \%$ guanine plus cytosine. Nitrogen-limited cells accumulate over $5 \%$ of their dry weight as a glycogen-like reserve material. This polysaccharide is a homoglucan which is similar to glycogen in its iodine-staining properties and its degree of degradation by phosphorylase $a$. Some of the glucose molecules are $\alpha$ 1,4 linked, and the presence of other types of bonds in the glucan is implied. The name of the genus proposed for these bacteria is Methylobacillus gen. nov. The name of the type species, Methylobacillus glycogenes sp. nov., refers to the ability of this species to form a glycogen-like reserve material. The type strain of $M$. glycogenes is T-11 (= ATCC 29475).
\end{abstract}

Methylotrophy has been defined as the "ability to grow nonautotrophically at the expense of carbon compounds containing one or more carbon atoms but containing no carbon to carbon bonds" (6). Molecules which contain one or more carbon atoms but no carbon-to-carbon bonds are referred to as one-carbon compounds. This includes molecules like dimethyl ether, dimethylamine, and the more obvious one-carbon compounds such as methane and methanol.

Currently, six genera of methylotrophic bacteria are recognized: Methylosinus (34); Methylocystis (34); Methylomonas (34); Methylobacter (34); Methylococcus (34); and Methylobacterium (26). Members of the last genus are characterized by the ability to grow on methane and methanol in addition to more complex carbon compounds containing carbon-to-carbon bonds $(25,26)$. The other genera include obligately methylotrophic bacteria for which only methane, dimethyl ether, and methanol can serve as carbon and energy sources $(27,34)$. It is evident by now that there is at least one other group of methylotrophic bacteria, namely obligate methylotrophs, which cannot grow on methane and dimethyl ether but do grow on one-carbon compounds other than methanol. Bacteria such as this have been described by several groups of workers $(5,7,8,14,24)$. The relationships of these bacteria are at the moment unclear; however, these organisms do not fit into any genus

1 Present address: HARLECO, Gibbstown, NJ 08027. of obligately methylotrophic bacteria so far described.

In this paper we describe a previously unreported obligate methylotroph which cannot grow on methane but which grows on methanol and methylamine and which synthesizes a glycogen-like compound for use as a reserve material. A name is proposed for this bacterium, and its taxonomic position is discussed.

\section{MATERIALS AND METHODS}

Bacterial strain. An enrichment culture was prepared by adding a small amount of partially decayed tomato to a liquid mineral salts medium containing $2 \%$ methanol ( $\mathrm{vol} / \mathrm{vol})$. The bacterium was isolated from the enrichment culture by streaking for isolated colonies on a mineral salts agar medium containing $2 \%$ methanol (vol/vol). A colony was picked and cultured in liquid mineral salts medium containing $2 \%$ methanol (vol/vol). This procedure was repeated until a pure culture was obtained. Several different isolates which could grow on methanol as the sole carbon and energy source were obtained in this manner. The isolate described in this paper was designated T-11.

Media. The medium used to cultivate T-11 is referred to as ammonium nitrate mineral salts medium (AN-MSM). It contains, per liter: $\mathrm{NH}_{4} \mathrm{NO}_{3}$, $2.0 \mathrm{~g} ; \mathrm{Na}_{2} \mathrm{HPO}_{4}, 1.4 \mathrm{~g} ; \mathrm{KH}_{2} \mathrm{PO}_{4}, 0.6 \mathrm{~g} ; \mathrm{MgSO}_{4} \cdot 7 \mathrm{H}_{2} \mathrm{O}$, $0.2 \mathrm{~g} ; \mathrm{CaCl}_{2} \cdot 2 \mathrm{H}_{2} \mathrm{O}, 0.01 \mathrm{~g} ; \mathrm{FeSO}_{4} \cdot 7 \mathrm{H}_{2} \mathrm{O}, 0.001 \mathrm{~g} ; 1$ $\mathrm{ml}$ of trace element solution; methanol at the level indicated; and distilled water to 1 liter. The trace element solution contains the following salts at a concentration of $20 \mathrm{mg} /$ liter of distilled water: $\mathrm{Na}_{2} \mathrm{MoO}_{4} \cdot 2 \mathrm{H}_{2} \mathrm{O} ; \quad \mathrm{Na}_{2} \mathrm{~B}_{4} \mathrm{O}_{7} \cdot 10 \mathrm{H}_{2} \mathrm{O} ; \quad \mathrm{ZnSO}_{4} \cdot \mathrm{H}_{2} \mathrm{O}$; 
$\mathrm{MnSO}_{4} \cdot \mathrm{H}_{2} \mathrm{O}$; and $\mathrm{CuSO}_{4} \cdot 5 \mathrm{H}_{2} \mathrm{O}$. The $\mathrm{pH}$ of the medium was adjusted to 7.0 with $\mathrm{NaOH}$ before autoclaving. Methanol was sterilized by filtration through a $0.22-\mu \mathrm{m}$-pore size, solvent-resistant membrane filter (Millipore Corp.) and aseptically added to the sterile salt solution. For a solid medium, either purified agar added to the AN-MSM at a level of $2 \%(\mathrm{wt} / \mathrm{vol})$ or plate-count agar (both obtained from Difco) was used. In both cases, after streaking, the plates were inverted and two drops of methanol were added to each lid. The plates were then incubated in a closed container at $30^{\circ} \mathrm{C}$. An additional two drops of methanol were added to each lid every 2 days.

Growth conditions. Strain T-11 was routinely cultured in stoppered $75-\mathrm{ml}$ serum bottles containing 25 $\mathrm{ml}$ of $4 \%$ methanol (vol/vol) AN-MSM. Unless stated otherwise, culturing was at $30^{\circ} \mathrm{C}$ with shaking at 200 to $250 \mathrm{rpm}$ in a New Brunswick PsycroTherm incubator. Liquid cultures were transferred weekly and stored at 0 to $4^{\circ} \mathrm{C}$. When large amounts of cells were needed, they were grown in 2-liter flasks containing $500 \mathrm{ml}$ of $1 \%$ methanol (vol/vol) AN-MSM. The flasks were sealed with rubber stoppers, and incubation was at $30^{\circ} \mathrm{C}$ with shaking.

Nutritional studies. In testing strain T-11 on various carbon sources, the basic medium used was ANMSM (minus methanol) to which the compound in question was added. The amino acid and some of the carbohydrate tests were performed in test tubes containing $5 \mathrm{ml}$ of medium. The remaining tests were done in $75-\mathrm{ml}$ serum bottles containing $25 \mathrm{ml}$ of medium. Each substrate was tested at least in duplicate, with several (methane, formaldehyde, formate, glucose) being tested five or six times. The tests were carried out at either 25 or $30^{\circ} \mathrm{C}$ with shaking. Since strain T-11 contains a reserve material, it was grown for $24 \mathrm{~h}$ in AN-MSM containing no methanol before being used to inoculate the test substrates. Appropriate controls were performed at all times. These consisted of $1 \%$ methanol ( $\mathrm{vol} / \mathrm{vol}$ ) AN-MSM, to examine the viability of the inoculum, and AN-MSM containing no carbon source, to examine for complete utilization of the reserve material. All tests were observed for at least 14 days.

The following substrates were sterilized by passage through a $0.22-\mu \mathrm{m}$-pore size membrane filter (Millipore Corp.) and aseptically added to the sterile basal salts: methanol, ethanol, $n$-propanol, isopropanol, $n$-butanol, methane, carbon dioxide, hydrogen, dimethyl ether, glucose, galactose, arabinose, fructose, lactose, mannose, melibiose, ribose, sucrose, xylose, formaldehyde, glucose-1-phosphate, glucose-6-phosphate, pyruvate, and polygalacturonic acid. Pectin was added to the basal salts, and the resulting solution was then sterilized by filtration. Methanol-free formaldehyde was generated from paraformaldehyde by heating a solution of paraformaldehyde in a boiling-water bath for $1 \mathrm{~h}$. The remaining substrates (Table 1) were sterilized by autoclaving (except for acetone, which was not sterilized).

The nitrogen utilization tests were done in the basic mineral salts medium minus ammonium ni- trate. The carbon source was methanol at $4 \%$ (vol/ vol), and the various nitrogen sources were added at a concentration of $1 \mathrm{~g} /$ liter (except for molecular nitrogen, which was added at a level of $10 \mathrm{~cm}^{3}$ per serum bottle, and nitrite, which was tested at a concentration of $1 \mathrm{mM}$ ). The inoculum was $0.1 \mathrm{ml}$ of a 24-h-old culture grown in nitrogen-limited $\mathrm{AN}$ MSM $\left(0.2 \mathrm{~g}\right.$ of $\mathrm{NH}_{4} \mathrm{NO}_{3}$ per liter). The tests were observed either until positive or up to 14 days. For both the carbon and nitrogen utilization tests, the criterion for a positive result was visible turbidity after two transfers in the medium.

Cultures in various stages of growth were examined by phase-contrast microscopy and by the spore stain of Schaeffer and Fulton (29) for the presence or absence of spores.

Determination of DNA base composition. Deoxyribonucleic acid (DNA) was isolated from strain T-11 by the method of Marmur (22). The moles percent guanine plus cytosine $(\mathrm{G}+\mathrm{C})$ was determined by $M$. Mandel (M.D. Anderson Hospital, Houston, Tex.) by using buoyant-density centrifugation (21).

Enzyme assays. Except for the methylamine dehydrogenase assay, the cells used in the enzyme assays were grown as described above. For the methylamine dehydrogenase assay, the cells were grown on $1 \%$ methylamine (wt/vol) AN-MSM. For all assays, the cells were grown for 16 to $20 \mathrm{~h}$, harvested in a Sorvall RC2 B refrigerated centrifuge, washed twice with sterile AN-MSM (minus methanol), resuspended in 2 volumes of sterile AN-MSM (minus methanol), and broken by two passages through a cold $\left(4^{\circ} \mathrm{C}\right)$ French pressure cell at 16,000 $\mathrm{lb} / \mathrm{in}^{2}$. To the resulting lysate was added an additional volume of sterile AN-MSM (minus methanol), and the suspension was centrifuged at $10,000 \times g$ for $15 \mathrm{~min}$. The supernatant from this centrifugation was recentrifuged at $48,000 \times g$ for $1 \mathrm{~h}$. The resulting supernatant was used for the enzyme assay, and it is referred to hereinafter as cell extract. If no enzyme activity was detected in the cell extract, the pellet obtained from the $48,000 \times g$ centrifugation was assayed. All centrifugations were performed at $0^{\circ} \mathrm{C}$. Optical density was measured on a Beckman model 25 spectrophotometer. Protein was measured by the method of Lowry et al. (19). Methanol-free formaldehyde was obtained by heating a solution of paraformaldehyde for $1 \mathrm{~h}$ in a boiling-water bath.

The nicotinamide adenine dinucleotide (phosphate) $[\mathrm{NAD}(\mathrm{P})]$-independent methanol dehydrogenase (EC 1.1.99.8) was assayed by the procedure described by Anthony and Zatman (3). The assay system for an NAD(P)-dependent methanol dehydrogenase contained the following in a total volume of 3 ml: $14 \mu \mathrm{mol}$ of methanol; $1.0 \mu \mathrm{mol}$ of oxidized NAD or oxidized NADP $\left(\mathrm{NAD}^{+}\right.$or $\left.\mathrm{NADP}^{+}\right)$; either 0.3 mmol of tris(hydroxymethyl)aminomethane (Tris) buffer (pH 9.0) or $0.2 \mathrm{mmol}$ of phosphate buffer ( $\mathrm{pH}$ 7.5); and $1.13 \mathrm{mg}$ of protein.

The formaldehyde dehydrogenase (EC 1.2.1.3) of strain T-11 was assayed by using a system in which a total volume of $1 \mathrm{ml}$ contained $0.5 \mu \mathrm{mol}$ of $\mathrm{NAD}^{+}$ or $\mathrm{NADP}^{+} ; 10 \mu \mathrm{mol}$ of formaldehyde; $50 \mu \mathrm{mol}$ of Tris-maleate buffer ( $\mathrm{pH} \mathrm{8.8);} \mathrm{and} \mathrm{cell} \mathrm{extract.} \mathrm{The}$ 
TABLE 1. Compounds that will not support the growth of Methylobacillus glycogenes at the levels indicated

\begin{tabular}{ll|ll}
\hline \multicolumn{1}{c|}{ Compound } & \multicolumn{1}{c}{$\%^{a}$} & \multicolumn{1}{c}{ Compound } & $\%^{a}$ \\
\hline Acetone & 0.1 & Galactose & 0.5 \\
Formaldehyde & $0.01,0.1$ & L-Arabinose & 0.5 \\
Formamide & 0.1 & Fructose & 0.5 \\
Dimethylformamide & 0.1 & Mannose & 0.5 \\
Dimethylamine & $0.1,1.0$ & Ribose & 0.5 \\
Formate $(\mathrm{Na})$ & $0.1,0.5$ & Xylose & 0.5 \\
Acetate $(\mathrm{Na})$ & 0.1 & Sucrose & 0.5 \\
Propionate $(\mathrm{Na})$ & 0.1 & Lactose & 0.5 \\
Butyrate $(\mathrm{Na})$ & 0.1 & Melibose & 0.5 \\
Lactate $(\mathrm{Na})$ & 0.1 & Polygalacturonic acid & 0.1 \\
Succinate $(\mathrm{Na})$ & Alanine & 1.0 \\
Oxalate $(\mathrm{Na})$ & $0.1,1.0$ & Aspargine & 1.0 \\
Citrate $\left(\mathrm{Na}, 2 \mathrm{H}_{2} \mathrm{O}\right)$ & $0.1,1.0$ & Glutamine & 1.0 \\
Malate $(\mathrm{Na})$ & 0.1 & Glycine & 1.0 \\
Fumarate $\left(\mathrm{Na}{ }_{2}\right)$ & 0.1 & Serine & 1.0 \\
Pyruvate $(\mathrm{Na})$ & 0.1 & Histidine & 1.0 \\
Gluconate $(\mathrm{Na})$ & 0.1 & Isoleucine & 1.0 \\
Ethanol & 0.1 & Lysine & 1.0 \\
$n$-Propanol & $0.1,0.5,1.0$ & Phenylalanine & 1.0 \\
iso-Propanol & $0.1,1.0$ & Proline & 1.0 \\
$n$-Butanol & $0.1,1.0$ & Valine & 1.0 \\
Glycerol & $0.1,1.0$ & Tryptone & $0.1,1.0$ \\
Inositol & 0.1 & Peptone & $0.1,1.0$ \\
Mannitol & $0.1,1.0$ & Gas & \\
Sorbitol & $0.1,1.0$ & Methane & $0.2^{b}$ \\
Glucose & $0.1,1.0$ & Dimethyl ether & $0.2^{b}$ \\
Glucose-1-phosphate $(\mathrm{Na})$ & $0.1,0.5$ & H & $0.4(0.2+0.2)^{b}$ \\
Glucose-6-phosphate $(\mathrm{Na})$ & 0.1 & & \\
\hline
\end{tabular}

a Percentage expressed as weight per volume except for acetone, formamide, dimethylformamide, sodium lactate, ethanol, $n$-propanol, iso-propanol, $n$-butanol, and glycerol, which are volume per volume.

b Expressed as milliliters per milliliter of headspace.

reaction was started by adding formaldehyde. To test for glutathione dependence, 2.0 or $4.0 \mu \mathrm{mol}$ of reduced glutathione was added to the above-mentioned assay system. In assaying for the presence of an NAD(P)-independent formaldehyde dehydrogenase, there were, in a total volume of $1 \mathrm{ml}$, either 50 $\mu \mathrm{mol}$ of Tris-maleate buffer ( $\mathrm{pH} \mathrm{8.8)}$ or $50 \mu \mathrm{mol}$ of phosphate buffer ( $\mathrm{pH} 7.0$ ); $10 \mu \mathrm{mol}$ of formaldehyde; $0.2 \mu \mathrm{mol}$ of 2,6-dichlorophenol indophenol $(2,6-$ DCPIP); $1 \mu \mathrm{mol}$ of phenazine methosulfate (PMS); and $0.92 \mathrm{mg}$ of protein. Optical density was read at $600 \mathrm{~nm}$ against a reference cuvette containing everything except 2,6-DCPIP. The reaction was started by adding formaldehyde.

Formate dehydrogenase (EC 1.2.1.2) was assayed by the method of Johnson and Quayle (12).

The NAD $(\mathrm{P})$-independent methylamine dehydrogenase (no EC number) was assayed using the method of Eady and Large (11). The assay for the NAD(P)-dependent methylamine dehydrogenase included $0.5 \mu \mathrm{mol}$ of $\mathrm{NAD}^{+}$or $\mathrm{NADP}^{+} ; 20 \mu \mathrm{mol}$ of methylamine; either $100 \mu \mathrm{mol}$ of Tris-maleate buffer (pH 8.8) or $100 \mu \mathrm{mol}$ of phosphate buffer (pH 7.0 ); and $0.65 \mathrm{mg}$ of protein. The reaction was started by adding methylamine.

3-Hexulose phosphate synthetase (no EC number) was assayed for by the procedure described by Dahl et al. (8), and hydroxypyruvate reductase (EC
1.1.1.81) was assayed for by the procedure described by Large and Quayle (16).

Characterization of reserve material. The method of Law and Slepecky (17) was used in attempts to isolate poly- $\beta$-hydroxybutyric acid. The cells used for the polysaccharide isolation were grown on $4 \%$ methanol (vol/vol) AN-MSM modified to contain $0.2 \mathrm{~g}$ of $\mathrm{NH}_{4} \mathrm{NO}_{3}$ per liter. A maximum of $600 \mathrm{ml}$ of medium was placed in a 2-liter flask. Incubation was at $30^{\circ} \mathrm{C}$ with shaking for $24 \mathrm{~h}$. The procedure used for isolating the polysaccharide was that described by Sigal et al. (31), and the polysaccharide was purified by repeated ethanol precipitations and precipitation with acetic acid.

Hydrolysis of the polysaccharide was accomplished by heating $10 \mathrm{mg}$ of the polysaccharide for $2 \mathrm{~h}$ at $100^{\circ} \mathrm{C}$ in $2 \mathrm{~N}$ sulfuric acid (total volume, $1 \mathrm{ml}$ ) in a sealed ampoule. At the end of the $2 \mathrm{~h}$, excess sulfuric acid was neutralized by adding solid barium carbonate. An additional $2 \mathrm{ml}$ of distilled water was added, and the suspension was centrifuged at 19,000 $\times g$ for $30 \mathrm{~min}$. The supernatant was removed and stored at $0^{\circ} \mathrm{C}$ when not being used. This procedure was used for both T-11 polysaccharide and rabbit liver glycogen.

Descending chromatography was performed on Whatman no. 1 paper. All standards (except the glycogen standard) were dissolved in pyridine, and 
$10 \mu \mathrm{g}$ of each standard and either $10 \mu \mathrm{g}$ or $100 \mu \mathrm{g}$ of the hydrolyzed polysaccharide and glycogen were used. After spotting the paper, the tank was allowed to equilibrate with the solvent for $5 \mathrm{~h}$ before starting the chromatogram. All chromatography was done at room temperature $\left(25\right.$ and $\left.27^{\circ} \mathrm{C}\right)$. The solvent systems used were: (i) ethyl acetate-pyridine-water (8:2:1) (vol/vol); (ii) $n$-butanol-pyridine-water $(6: 4: 3)$ (vol/vol); and (iii) $n$-propanol-water-ethyl acetate $(7: 2: 1)(\mathrm{vol} / \mathrm{vol})$. The chromatograms were allowed to run for $24 \mathrm{~h}$ except that when solvent system (i) was used, a 36-h run was necessary for good resolution. The chromatograms were developed using the ammoniacal silver nitrate reagent described by Sherma and Zweig (30). This reagent has a sensitivity of 1 $\mu \mathrm{g}$ of reducing sugar.

The iodine absorption spectrum was obtained by using a Perkin Elmer model 356 spectrophotometer and model 56 recorder following the procedure of Archibald et al. (4).

In determining the percent degradation of the polysaccharides by phosphorylase $a$ (EC 2.4.1.1), the following were used in a total volume of $5 \mathrm{ml}: 5 \mathrm{mg}$ of T-11 polysaccharide or rabbit liver glycogen; 250 $\mu$ mol of sodium arsenate; $15 \mathrm{U}$ of phosphorylase $a$; and $0.43 \mathrm{mmol}$ of Tris-maleate buffer (pH 6.8). Incubation was at $30^{\circ} \mathrm{C}$. At intervals, $0.5-\mathrm{ml}$ samples were withdrawn, and the reaction was stopped by adding $0.5 \mathrm{ml}$ of distilled water and $1 \mathrm{ml}$ of $0.15 \mathrm{~N}$ sodium hydroxide. After mixing, $1.0 \mathrm{ml}$ of $2 \%$ zinc sulfate (wt/vol) was added, and the suspension was mixed again and then centrifuged at $12,000 \times g$ for $10 \mathrm{~min}$. A 2 -ml volume of the supernatant was taken as the sample, and the glucose contained therein was measured using Worthington Glucostat Special reagent. This procedure is based on phosphorylase $a$ degrading the glycogen to glucose-1-arsenate, which spontaneously breaks down to glucose and arsenate (13). Since the phosphorylase $a$ contained a small amount of contaminating amylo-1,6-glucosidase (EC 3.2 .1 .33 ), the extent of degradation of glycogen by phosphorylase $a$ was taken as the end of the initial rapid rise in glucose production.

Extracellular polysaccharides. To check for the production of extracellular polysaccharides by strain T-11, a capsule stain was done, and the medium in which T-11 had been grown was examined for soluble polysaccharides. The capsule stain was performed by Maneval's method (20) using strains of Klebsiella pneumoniae and Escherichia coli as positive controls. For this procedure, one loopful of $1 \%$ Congo Red (wt/vol) was mixed with one loopful of bacterial suspension, and the mixture was air dried. The stain was flooded with Maneval solution and left standing for $2 \mathrm{~min}$, after which time the dye was washed off, and the slide was air dried and observed microscopically under oil. Using this procedure, cells are red, the background is blue, and capsules are colorless. Maneval solution was made by adding to $30 \mathrm{ml}$ of $5 \%$ phenol (wt/vol) $10 \mathrm{ml}$ of $20 \%$ acetic acid (vol/vol), $4 \mathrm{ml}$ of $30 \%$ ferric chloride (wt/vol), and $2 \mathrm{ml}$ of $1 \%$ acid fuchsin (wt/vol) and mixing thoroughly. The presence of soluble polysaccharides was examined by centrifuging the cells out of a 24-h-old culture and adding 2 volumes of $95 \%$ ethanol (vol $/ \mathrm{vol})$. The solution was then centrifuged at $20,000 \times g$ for $20 \mathrm{~min}$.

Electron microscopy. A drop of $\mathrm{T}-11$ culture was dried on a 100- to 200-mesh Formvar-coated copper grid. The grid was shadowed at $45^{\circ}$ with platinum and examined using a JEM 7 A electron microscope.

\section{RESULTS}

General characteristics of strain T-11. Cells of T-11 grown on $4 \%$ methanol (vol/vol) ANMSM are rods, 0.5 to 0.8 by 1.0 to $1.6 \mu \mathrm{m}$ in size, which occur singly and in pairs in all stages of growth (Fig. 1). The cells are nonmotile in all phases of growth. Neither a capsule nor a soluble extracellular polysaccharide is formed when the cells are grown on either normal or nitrogen-limited 4\% methanol (vol/vol) AN-MSM. The cells are obligately aerobic, gram negative, catalase positive, oxidase positive, and reduce nitrate. No growth occurs anaerobically in the presence of nitrate. On AN-MSM agar incubated above methanol, the colonies are colorless, becoming pale yellow around 7 to 9 days, convex, round, entire, smooth, and glistening. Forty-eight-hour-old colonies are $0.4 \mathrm{~mm}$ in diameter, and the colony diameter on this medium has not been observed to exceed $3.0 \mathrm{~mm}$. On plate-count agar incubated above methanol, the colonies have the same morphology as on AN-MSM agar except that they are white and

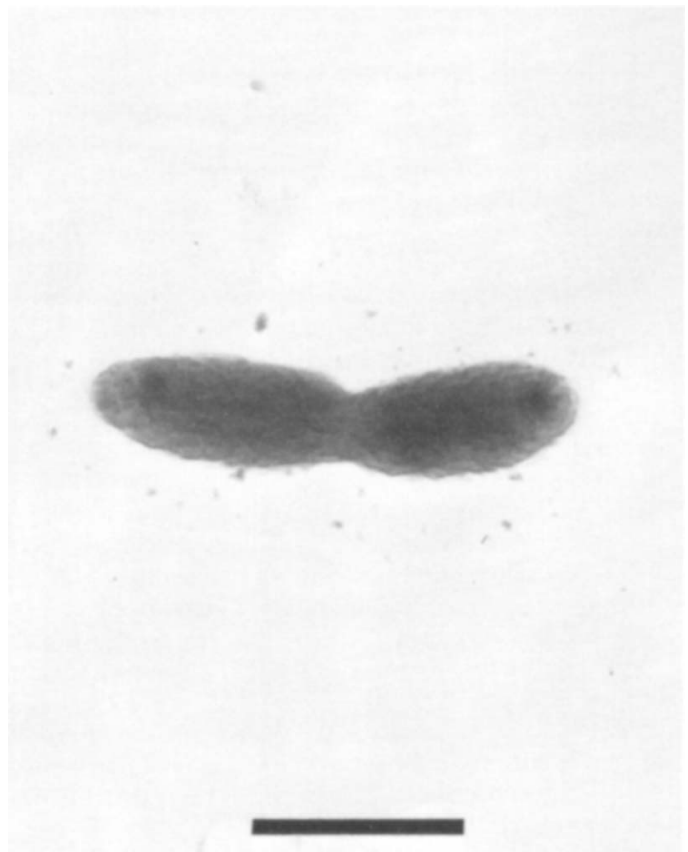

FIG. 1. Electron micrograph of Methylobacillus glycogenes strain T-11. The bar represents a length of $1.0 \mu \mathrm{m}$. 
do not become yellow and the colony size is larger. After $48 \mathrm{~h}$, the colony diameter is $\mathbf{1 . 0}$ $\mathrm{mm}$, and it has not been observed to exceed 4.0 $\mathrm{mm}$ on plate-count agar incubated above methanol. In unshaken $4 \%$ methanol (vol/vol) ANMSM, growth is uniformly distributed and is colorless; however, a pellet of cells grown in the same medium is bright pink. Strain T-11 DNA has a buoyant density of 1.713 , which corresponds to $54.1 \mathrm{~mol} \% \mathrm{G}+\mathrm{C}$.

Strain T-11 grows equally well from 20 to $30^{\circ} \mathrm{C}$, with no growth occurring at $37^{\circ} \mathrm{C}$ and little if any growth occurring at $15^{\circ} \mathrm{C}$. The $\mathrm{pH}$ limits for growth of this bacterium are from $\mathrm{pH}$ 6.0 to $\mathrm{pH} 9.5$, with the optimum $\mathrm{pH}$ at 7.0. At a methanol concentration of 0.5 to $2.0 \%$ ( $\mathrm{vol} / \mathrm{vol}$ ), the mean doubling time is $3.4 \pm 0.5 \mathrm{~h}$; at 3 and $4 \%$ methanol ( $\mathrm{vol} / \mathrm{vol})$, the mean doubling time is $4.5 \pm 0.6 \mathrm{~h}$; and no growth occurs at $5 \%$ methanol (vol/vol).

Nutrition. Strain T-11 cannot grow on tomato juice agar, skim milk agar, blood agar, egg yolk agar, or plate-count agar when depending on the carbon compounds in these media as the sole source of carbon and energy. After $24 \mathrm{~h}$ of growth in 4\% methanol (vol/vol) AN-MSM, cells streaked onto plate-count agar will produce 0.5 -mm-diameter colonies after 4 days. Table 1 lists the carbon sources which were tested and found unable to support growth of T-11. The only carbon compounds found to support growth of T-11 are methanol, methylamine, and pectin.

Nitrate, nitrite, ammonium, urea, glutamine, and tryptone can all serve as nitrogen sources for T-11, whereas molecular nitrogen could not serve as the nitrogen source for growth under the aerobic conditions of the test.

Enzyme activities. Table 2 lists the activities of the enzymes involved in one-carbon metabolism detected in T-11 cell extracts. For all the enzymes, there was a range of protein concen-

TABLE 2. Enzyme activities present in Methylobacillus glycogenes cell extracts

\begin{tabular}{|c|c|}
\hline Enzyme & Activity $^{a}$ \\
\hline $\begin{array}{l}\text { NAD }(\mathrm{P}) \text {-independent methanol dehydro- } \\
\text { genase } \ldots \ldots \ldots \ldots \ldots \ldots \ldots \ldots \ldots \ldots\end{array}$ & 0.011 \\
\hline $\begin{array}{l}\text { NAD-dependent formaldehyde dehydro- } \\
\text { genase } \ldots \ldots \ldots \ldots \ldots \ldots \ldots \ldots \ldots \ldots\end{array}$ & 0.063 \\
\hline NAD-dependent formate dehydrogenase & 0.003 \\
\hline $\begin{array}{l}\text { NAD }(P) \text {-independent methylamine de- } \\
\text { hydrogenase } \ldots \ldots \ldots \ldots \ldots \ldots \ldots \ldots\end{array}$ & 0.157 \\
\hline 3-Hexulose phosphate synthetase ...... & 1.299 \\
\hline Hydroxypyruvate reductase ........ & 0.011 \\
\hline
\end{tabular}

${ }^{a}$ Micromoles of product formed per minute per milligram of protein corrected for activity (if any) in the absence of substrate and enzyme. trations over which a linear relationship existed between enzyme activity and the amount of protein in the assay system. The following enzymes could not be detected: NAD(P)-dependent methanol or methylamine dehydrogenases; NADP-dependent or NAD(P)-independent formaldehyde dehydrogenase. The formaldehyde dehydrogenase did not require the addition of reduced glutathione for activity, and adding reduced glutathione did not increase the activity of this enzyme. The methanol dehydrogenase has an apparent $K_{m}$ (in crude cell extracts) of $14 \mu \mathrm{M}$ methanol.

Characterization of reserve material. Poly$\beta$-hydroxybutyric acid could not be isolated from normally grown or nitrogen-limited cells. However, by using the procedure described in Materials and Methods, a white material was isolated from nitrogen-limited cells. During subsequent purification, this material behaved like a polysaccharide: it could be precipitated from solution by the addition of 1 volume of ethanol or 4 volumes of acetic acid; it went from a powder through a gel phase while dissolving in water; and aqueous solutions of the material were opalescent.

Paper chromatography of the acid-hydrolyzed product revealed one major spot which cochromatographed with both glucose and the major spot from acid-hydrolyzed rabbit liver glycogen. This was observed in all three solvent systems. In none of the instances was there a spot for the material isolated from T-11 which was not matched by a similar spot for the rabbit liver glycogen. Both had additional minor spots corresponding to maltose and malotriose, presumably due to incomplete hydrolysis.

The iodine absorption spectrum of T-11 polysaccharide when complexed with iodine is shown in Fig. 2. The wavelengths of maximum absorbance are $444 \mathrm{~nm}$ and $480 \mathrm{~nm}$ for T-11 polysaccharide and rabbit liver glycogen, respectively, with the maximum absorbances being 0.112 and 0.291 , respectively. The polysaccharide isolated from T-11 is degraded $16 \%$ by phosphorylase $a$ as compared to a degradation of rabbit liver glycogen of $33.7 \%$ by the same enzyme.

\section{DISCUSSION}

Strain T-11 is clearly an obligate methylotroph. The fact that growth occurs on platecount agar when the inoculum is grown in $4 \%$ methanol ( $\mathrm{vol} / \mathrm{vol})$ is due to methanol carried over in the inoculum and to the internal reserve material. When T-11 is starved to eliminate the internal reserve material, no growth occurs on plate count agar. The only multi- 


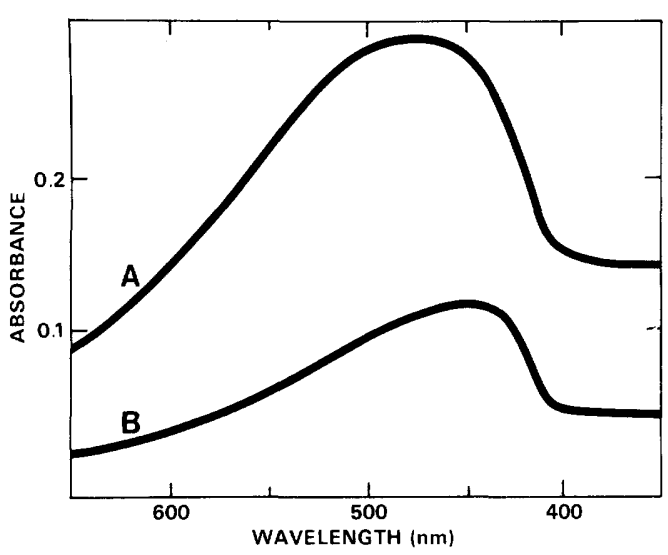

FIG. 2. Absorption spectra of glycogen-iodine complexes. (A) Rabbit liver glycogen-iodine complex; (B) Methylobacillus glycogenes homoglucan-iodine complex.

carbon compound tested which could support growth of T-11 was pectin. Since polygalacturonic acid was unable to support growth, the methyl esters in the pectin must have been the actual substrate. Strain T-11 was isolated from a decaying tomato, and it is very likely that the carbon compound serving as its natural source of energy was the esterified methyl groups on tomato pectin.

Cell extracts of T-11 contain an NAD(P)-independent methanol dehydrogenase which can be linked to PMS and 2,6-DCPIP. This type of enzyme was first described by Anthony and Zatman (3), and it has since been found in many facultative and obligate methylotrophs (2). An NAD(P)-independent methylamine dehydrogenase is also present in methylaminegrown T-11 cell extracts. This enzyme can also be linked to PMS and 2,6-DCPIP, and it is similar in that respect to the enzyme described by Eady and Large (11). The formaldehyde dehydrogenase found in T-11 appears to be a glutathione-independent, NAD-linked enzyme, although studies on the purified enzyme would be required to prove this. This type of enzyme is a nonspecific aldehyde dehydrogenase which does not appear to be very widespread among methylotrophs. This type of enzyme has been reported in bacterium 4B6 (7), an obligate methylotroph, and in Pseudomonas MS (15), a facultative methylotroph. Neither of these bacteria can grow on methanol; instead they grow methylotrophically on various methylamine compounds.

The presence of 3-hexulose phosphate synthetase and hydroxypyruvate reductase in cell extracts of T-11 suggests that both the serine pathway and the 3-hexulose phosphate path- way might operate for the fixation of formaldehyde in T-11. However, the activity of 3-hexulose phosphate synthetase is about 118 times greater than the activity of hydroxypyruvate reductase, and therefore the major pathway for formaldehyde fixation is the hexulose phosphate pathway. The enzymes of the serine pathway are probably used mainly for amino acid biosynthesis rather than for formaldehyde fixation.

Chromatography of the hydrolysis product of the material isolated from T-11 shows that it cochromatographs with glucose and the hydrolysis product of rabbit liver glycogen. Since the sensitivity of the developing reagent is $1 \mu \mathrm{g}$ of reducing sugar, the fact that no other spots appeared on the chromatograms to which 100 $\mu \mathrm{g}$ of hydrolysate was applied indicates that any reducing sugar which may be present in the polysaccharide (other than glucose) comprises less than $1 \%$ of the total.

The maximum absorbance of the T-11 homoglucan-iodine complex is considerably lower than the maximum absorbance of rabbit liver glycogen-iodine complex. This kind of result appears to be typical of invertebrate glycogeniodine complexes $(4,31)$. Archibald et al. (4) reported that the iodine-staining power of $\alpha$ 1,4-glucans is not dependent on the branching characteristics of the glucan but instead depends on the source of the glucan. Mammalian glycogens when complexed with iodine give a red-brown color whereas invertebrate glycogens under the same conditions are more yellow-brown. Amylopectin-iodine complexes characteristically have wavelengths of maximum absorbance located at higher wavelengths than glycogen-iodine complexes (4). Typical wavelength maxima for amylopectin-iodine complexes range from 500 to $535 \mathrm{~nm}$. In addition, these complexes absorb more strongly then glycogen-iodine complexes with absorbances of 1.0 being common (4). This spectrum shows that T-11 homoglucan is not starchlike but is more similar to a glycogen, at least in its iodine-staining ability.

The extent of degradation of glycogens by phosphorylase $a$ is around $20 \%$ to $30 \%$ (23). The glucan isolated from T-11 is degraded to a slightly lesser extent; however, it is still close to the limits for glycogen. Amylopectin, on the other hand, is degraded 35 to $45 \%$ by phosphorylase $a$ (23). Since phosphorylase $a$ is specific for $\alpha-1,4$-glucose bonds, the fact that T-11 glucan is degraded by phosphorylase $a$ shows that some of the glucose molecules are $\alpha-1,4$ linked. $\mathrm{T}-11$ glucan is not degraded completely by phosphorylase $a$, which implies that bonds other than $\alpha-1,4$ are present. It is not known at 
present if there are $\alpha-1,6$ branch points.

The statement that an obligate methylotroph synthesizes and uses a glycogen-like reserve material on first consideration seems inconsistent. However, the nitrogen-limited T-11 has been found to accumulate over $5 \%$ of its dry weight as a glycogen-like compound. In addition, Stanier et al. (32) have shown that $R$ hodospirillum rubrum will accumulate glycogen even though it too cannot grow on glucose. Figure 3 shows one possible mechanism of how glycogen accumulation and utilization could occur in an obligate methylotroph. Methanol is first oxidized to formaldehyde, which can then either be further oxidized to formate and then $\mathrm{CO}_{2}$ or fixed into fructose-6-phosphate via the hexulose phosphate cycle. For every six molecules of formaldehyde fixed, the net result is two molecules of 3-phosphoglyceraldehyde (33). These could be condensed and then converted to glucose-1-phosphate. Assuming glycogen synthesis occurs in the same manner as in other bacteria, an adenosine diphosphoryl glucose pyrophosphorylase (no EC number) and an $\alpha-1,4-$ glucan synthetase (no EC number) would be involved (10). By using two independent assay systems, we have detected an $\alpha$-1,4-glucan synthetase in extracts of nitrogen-limited T-11. At no point in this scheme, from the time formal- dehyde is fixed into a hexose phosphate until it is incorporated into glycogen, would there have to be an unphosphorylated compound. If the glycogen were degraded by a phosphorylase similar to those currently known to exist in other bacteria, glucose-1-phosphate would be the product (10). Again, there would be no unphosphorylated intermediates. A possible explanation of why T-11 cannot grow on glucose but can grow on glycogen could be that the bacterium lacks the enzymes necessary either to phosphorylate or to transport glucose. Ameniya (1) came to a similar conclusion concerning the inability of Methylomonas methanooxidans to grow on glucose. He was unable to find glucokinase in $M$. methanooxidans. In this instance, however, glucose-6-phosphate could support growth. Neither glucose-6-phosphate nor glucose-1-phosphate can support growth of T-11.

Although T-11 is an obligate methylotroph, it does not fit into any of the genera of obligate methylotrophs currently recognized. The genus to which it appears most closely related is Methylomonas; however, this genus is restricted to those bacteria for which only methane and methanol serve as carbon and energy sources (18). T-11 cannot utilize methane and can grow on methylamine. Other obligate

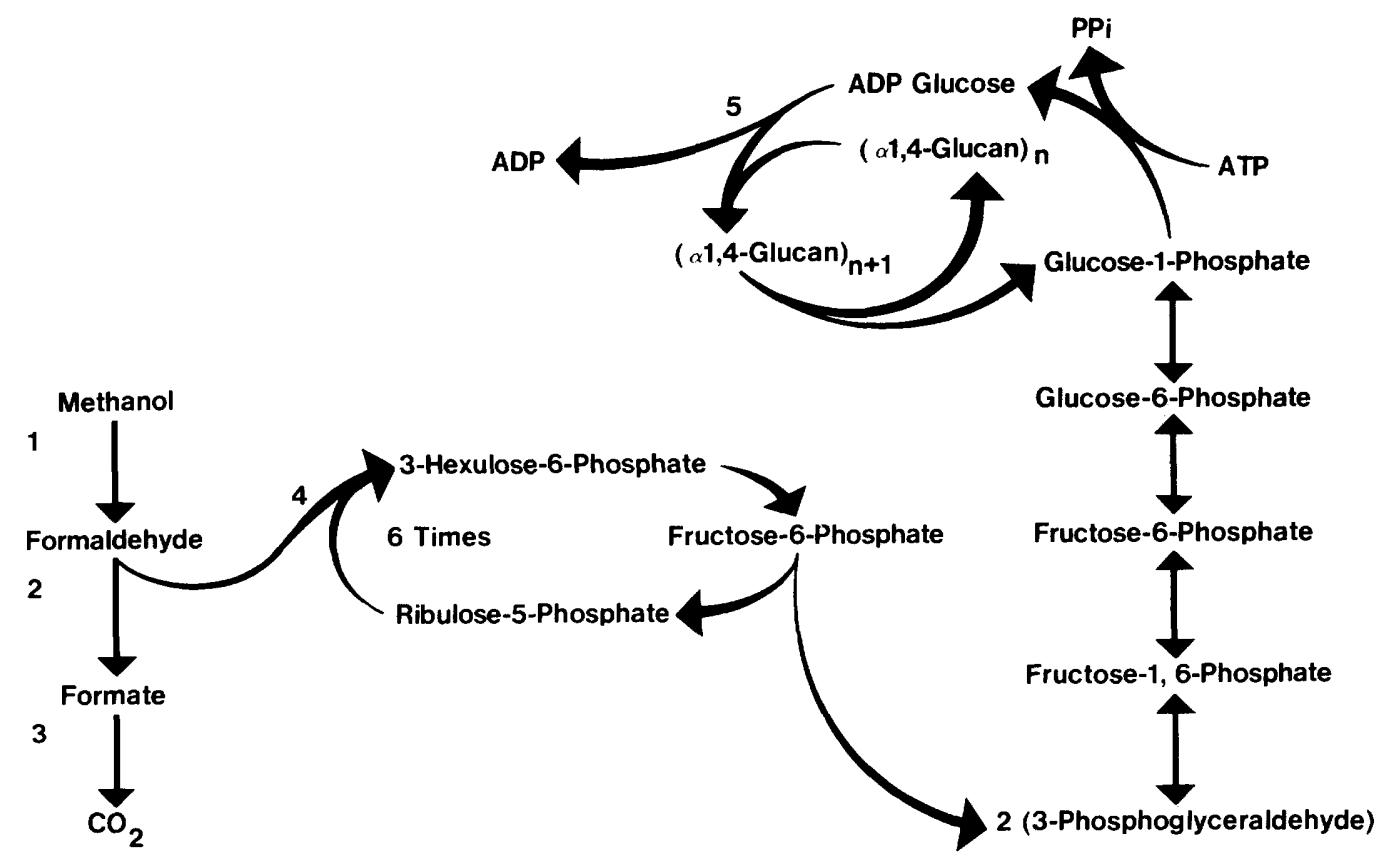

Fig. 3. Possible mechanism for synthesis and degradation of glycogen by an obligate methylotroph. The enzymes indicated have all been detected in Methylobacillus glycogenes cell extracts: (1) NAD (P)-independent methanol dehydrogenase; (2) formaldehyde dehydrogenase; (3) formate dehydrogenase; (4) 3-hexulose phosphate synthetase; and (5) $\alpha-1,4$-glucan synthetase. 
TABLE 3. Carbon sources for non-methane-utilizing obligate methylotrophs ${ }^{a}$

\begin{tabular}{|c|c|c|c|c|c|c|}
\hline Methylotroph & Methanol & Formaldehyde & Methylamine & $\begin{array}{l}\text { Dimethylam- } \\
\text { ine }\end{array}$ & $\begin{array}{l}\text { Trimethyl- } \\
\text { amine }\end{array}$ & Reference \\
\hline Pseudomonas $\mathrm{RJ} 3$ & + & - & + & NR & NR & 24 \\
\hline Bacterium W 1 & + & - & + & NR & NR & 8 \\
\hline Bacterium & + & + & NR & NR & NR & 5 \\
\hline Bacterium & - & NR & + & + & + & 7 \\
\hline Bacterium & + & NR & + & + & + & 7 \\
\hline
\end{tabular}

${ }^{a}$ None of the isolates grow on methane or formate. Symbols: + , growth; - , no growth; NR, not reported.

methylotrophs have also been isolated which cannot grow on methane and which can utilize one-carbon compounds other than methanol (Table 3). The classification of these bacteria in the genus Methylomonas would require changing the description of the genus. We feel this would not be prudent due to the great difference between methane oxidizers and non-methane-oxidizing obligate methylotrophs. Bacteria that can grow on methane form a complex system of internal membranes $(9,28)$ which has never been seen in non-methane-utilizing obligate methylotrophs (8). The fact that non-methane-oxidizing obligate methylotrophs are very numerous and widespread (14) leads one to believe that they are not just methane oxidizers which have mutated on isolation but that they comprise a separate taxon.

We believe that T-11 and other obligate methylotrophs which can grow on one-carbon compounds other than methane and methanol should be included in a new genus. We are proposing for this genus the name Methylobacillus (Meth.yl.o.ba.cil'.lus. M.L. noun methyl the methyl radical; L. dim. noun bacillus a small rod; M.L. masc. noun Methylobacillus methyl rodlet). The type species of Methylobacillus is $M$. glycogenes (gly.co'.gen.es. Gr. adj. glyks sweet; Gr. v. gennairo to produce; Gr. adj. glycogenes sweet-producing, intended to mean sugar-producing, glycogen-producing). The type strain of $M$. glycogenes, T-11, has been deposited with the American Type Culture Collection (ATCC), Rockville, Md., under the accession number 29475 .

Methylobacillus gen. nov. Short, gram-negative rods. Obligate methylotrophs which grow on one-carbon compounds other than methanol and which cannot grow on methane and dimethyl ether. Strict aerobes; metabolism is respiratory. The $\mathrm{G}+\mathrm{C}$ content of the DNA of the type species as determined by buoyant-density centrifugation is $54.1 \mathrm{~mol} \%$.

Methylobacillus glycogenes sp. nov. Nonmotile rods, 0.5 to 0.8 by 1.0 to $1.6 \mu \mathrm{m}$, occurring singly and in pairs. No resting stages are formed. No capsules or soluble extracellular polysaccharides are produced. Colorless, be- coming pale yellow in 7 to 9 days, convex, round, entire, smooth, and glistening colonies are produced on a mineral salts medium (ANMSM) with methanol as the carbon source. Methanol and methylamine are the only carbon compounds capable of supporting growth. A wide variety of inorganic and organic nitrogen compounds can be used as nitrogen sources. Temperature relationship: growth occurs equally well between 20 and $30^{\circ} \mathrm{C}$. $\mathrm{pH}$ relationships: growth occurs between $\mathrm{pH} 6.0$ and 9.5; the $\mathrm{pH}$ for optimum growth is 7.0. Catalasepositive and oxidase-positive; the 3-hexulose phosphate pathway is used for formaldehyde fixation. Nitrogen-limited cells accumulate a glycogen-like reserve material.

Because this species description is based on a single strain-T-11, the type strain-it also serves as the description of the type strain.

\section{ACKNOWLEDGMENTS}

We thank Manley Mandel for the base ratio determination on T-11 deoxyribonucleic acid and Harry W. Seeley, $\mathrm{Jr}$., for his interest and help in preparing the manuscript.

This research was supported by federal funds received via the Hatch Act.

\section{REPRINT REQUESTS}

Address reprint requests to: $\mathrm{Dr}$. T. L. Weaver, HARLECO, 480 Democrat Road, Gibbstown, NJ 08027.

\section{LITERATURE CITED}

1. Ameniya, K. 1972. Absence of glucokinase in Methanomonas sp. as a cause for their inability to grow on glucose. Can. J. Microbiol. 18:1907-1913.

2. Anthony, C. 1975 . The biochemistry of methylotrophic micro-organisms. Sci. Prog. Oxford 62:167-206.

3. Anthony, C., and L. J. Zatman. 1964. The microbial oxidation of methanol. 2. The methanol-oxidizing enzyme of Pseudomonas sp. M 27. Biochem. J. 92:614621.

4. Archibald, A. R., I. D. Fleming, A. M. Liddle, D. J. Manners, G. A. Mercer, and A. Wright. 1961. $\alpha-1,4-$ Glucosans. XI. The absorption spectra of glycogenand amylopectin-iodine complexes. J. Chem. Soc. p. 1183-1190.

5. Chen, B. J., W. Hirt, H. C. Lin, and G. T. Tsao. 1977. Growth characteristics of a new methylomonad. Appl. Environ. Microbiol. 33:269-274.

6. Colby, J., and L. J. Zatman. 1972. Hexose phosphate synthetase and tricarboxylic acid-cycle enzymes in bacterium $4 \mathrm{~B} 6$, an obligate methylotroph. Biochem. J. 128:1373-1376.

7. Colby, J., and L. J. Zatman. 1973. Trimethylamine 
metabolism in obligate and facultative methylotrophs. Biochem. J. 132:101-112.

8. Dahl, J. S., R. J. Mehta, and D. S. Hoare. 1972. New obligate methylotroph. J. Bacteriol. 109:916-921.

9. Davies, S. L., and R. Whittenbury. 1970. Fine structure of methane and other hydrocarbon-utilizing bacteria. J. Gen. Microbiol. 61:227-232.

10. Dawes, E. A., and P. J. Senior. 1973. The role and regulation of energy reserve polymers in micro-organisms, p. 135-266. In A. H. Rose and D. W. Tempest (ed.), Advances in microbial physiology, vol. 10. Academic Press Inc., New York.

11. Eady, R. R., and P. J. Large. 1968. Purification and properties of an amine dehydrogenase from Pseudomonas AM 1 and its role in growth on methylamine. Biochem. J. 106:245-255.

12. Johnson, P. A., and J. R. Quayle. 1964. Microbial growth on $\mathrm{C}_{1}$-compounds. 6. Oxidation of methanol, formaldehyde, and formate by methanol-grown $P$ seudomonas AM 1. Biochem. J. 93:281-290.

13. Katz, J., and W. Z. Hassid. 1951. Arsenolysis of amylose and amylopectin. Arch. Biochem. 30:272-281.

14. Kouno, K., and A. Ozaki. 1975. Distribution and identification of methanol-utilizing bacteria, p. 11-21. In Microbial growth on $\mathrm{C}_{1}$-compounds. Nakanishi Printing Co., Ltd., Kyoto, Japan.

15. Kung, H. F., and C. Wagner. 1970. Oxidation of $\mathrm{C}_{1}$ compounds by Pseudomonas sp. MS. Biochem. J. 116:357-365.

16. Large, P. J., and J. R. Quayle. 1963. Microbial growth on $C_{1}$ compounds. 5. Enzyme activities in extracts of Pseudomonas AM 1. Biochem. J. 87:386-396.

17. Law, J. H., and R. A. Slepecky. 1961. Assay of poly- $\beta$ hydroxybutyric acid. J. Bacteriol. 82:33-36.

18. Leadbetter, E. R. 1974. Methylomonadaceae, p. 627629. In R. E. Buchanan and N. E. Gibbons (ed.), Bergey's manual of determinative bacteriology, 8th ed. The Williams and Wilkins Co., Baltimore.

19. Lowry, O. H., N. J. Rosebrough, A. L. Farr, and R. J. Randall. 1951. Protein measurement with the Folin phenol reagent. J. Biol. Chem. 193:265-275.

20. Maneval, W. E. 1941. Staining bacteria and yeasts with acid dyes. Stain Technol. 16:13-19.

21. Mandel, M. 1966. Deoxyribonucleic acid base composition in the genus Pseudomonas. J. Gen. Microbiol. 43:273-292.

22. Marmur, J. 1961. A procedure for the isolation of deoxy- ribonucleic acid from micro-organisms. J. Mol. Biol. 3:208-218.

23. Marshall, J. J. 1974. Application of enzymic methods to the structural analysis of polysaccharides, p. 257-370. In R. S. Tipson and D. Horton (ed.), Advances in carbohydrate chemistry and biochemistry, vol. 30 . Academic Press Inc., New York.

24. Mehta, R. J. 1973. Studies on methanol-oxidizing bacteria. 1. Isolation and growth studies. Antonie van Leeuwenhoek. J. Microbiol. Serol. 39:295-302.

25. Patt, T. E., G. C. Cole, J. Bland, and R. S. Hanson. 1974. Isolation and characterization of bacteria that grow on methane and organic compounds as sole sources of carbon and energy. J. Bacteriol. 120:955964.

26. Patt, T. E., G. C. Cole, and R. S. Hanson. 1976. Methylobacterium, a new genus of facultatively methylotrophic bacteria. Int. J. Syst. Bacteriol. 26:226-229.

27. Quayle, J. R. 1972. The metabolism of one-carbon compounds by microorganisms, p. 119-203. In A. H. Rose and D. W. Tempest (ed.), Advances in microbial physiology, vol. 7. Academic Press Inc., New York.

28. Ribbons, D. W., J. E. Harrison, and A. M. Wadzinski. 1970. Metabolism of single carbon compounds. Annu. Rev. Microbiol. 24:135-158.

29. Schaeffer, A. B., and McD. Fulton. 1933. A simplified method of staining endospores. Science 77:194.

30. Sherma, J., and G. Zweig. 1971. Paper chromatography and electrophoresis, vol. 2, p. 158. Academic Press Inc., New York.

31. Sigal, N., J. Cattaneo, and I. H. Segel. 1964. Glycogen accumulation by wild-type and uridine diphosphate glucose pyrophosphorylase-negative strains of Escherichia coli. Arch. Biochem. Biophys. 108:440-451.

32. Stanier, R. Y., M. Doudoroff, R. Kunisawa, and R. Contopoulou. 1959. The role of organic substrates in bacterial photosynthesis. Proc. Natl. Acad. Sci. U.S.A. 45:1246-1260.

33. Strøm, T., T. Ferenci, and J. R. Quayle. 1974. The carbon assimilation pathways of Methylococcus capsulatus, Pseudomonas methanica, and Methylosinus trichosporum (OB3B) during growth on methane. Biochem. J. 144:465-476.

34. Whittenbury, R., K. C. Phillips, and J. F. Wilkinson. 1970. Enrichment isolation, and some properties of methane-utilizing bacteria. J. Gen. Microbiol. 61:205-218. 